\title{
Develop Character-Based Learning Model With Multicultural Scientific Approach to Increase Learning Quality in History Education
}

\author{
Samsidar Tanjung \\ Department of Educational Technology \\ Faculty of Postgraduate Program \\ State University of Medan \\ Medan, Indonesia \\ Corresponding email: samsidartanjung55@gmail.com
}

\begin{abstract}
This study aims to produce a character-based learning model with a multicultural scientific approach with historical education materials and know the feasibility and effectiveness of the learning model to be able to improve the learning outcomes of history education. This type of research is a research and development consisting of three stages, namely the preparation of programs/concepts, product development and evaluation. Stages of programming/concepts include determining learning objectives, formulation of learning materials, developing learning models, determining learning strategies, and designing and formulating formative evaluations and defining applications. The second step is product development which involves making the design of character-based learning model of multicultural scientific approach through learning device, material collecting, and assembly or organizing materials. The next process is a product evaluation consisting of several stages of material expert validation and validation of media experts, individual trials, small group trials, and field trials. The test results show that the average score of the aspects of the learning model is very good, the material / content is very good and the media /display aspect is very good. The results showed that the quality of learning models with historical education materials is worth using, and can effectively improve learning outcomes.
\end{abstract}

Keywords - component: learning model; character; scientific; multicultural; historical education

\section{INTRODUCTION}

One of the impacts of the crisis in science, almost all disciplines of science are questioned "the contribution of its efficacy" to restoring the multidimensional crisis, including the role of learning history in maintaining the integration of the nation. Some social historians and observers argue that nationalism concerning the integration of the nation needs to be "revitalized" in a broad sense concerning the shift of the historical to historical view, its development towards egalitarism, justice, clean governance and clean government which accelerates the realization of civil society so as not to lose its actuality [1] , [2], [3], [4].

The importance of changing the paradigm of historical education is not solely because of the recent reform movement, the reform movement itself is only a factor triggering the movement in that direction. Pioneered the change from the Old History to The New History, a reaction to the overly rigid Old History limiting itself to political history [5]. The expansion of the assessment on New History includes aspects of economics, socio-culture, agriculture, education, psychology, technology, and so on inter / multidisciplinary. It seems that there has been such a shift in change in the philosophy of historical education from perenialism that emphasizes "transmission of the glorious past" toward a position in which philosophical flows such as essensialism and even social reconstructionism merge into it eclectically [6].

This eclectic historical lesson is not only a vehicle for the development of intellectual ability and pride of the past, but also a vehicle for improving people's lives in the political, economic, social, and cultural fields. Historical learning also has practical-pragmatic values for students, not just theoretical values-conceptual idealism. As a logical consequence of the shift in philosophy of historical learning, there are three new things; (1) the relation of history lessons to the daily life of the students; (2) understanding and awareness of the characteristics of historical stories that are not final; and (3) the expansion of the theme of political history with themes of social, cultural, economic, and technological history [7].

The study of national history as an element of the development of cultural nationalism is very useful to mediate in strengthening the relationship between the elements of plural society. Anderson [8] mentions the role of national history as a national identity and the development of national consciousness. Furthermore he also sees the importance of national identity as the most powerful and lasting influence in collective cultural identity.

The historical-epistemological evolution of the multicultural curriculum, began in 1960 when the civil rights movement emerged as a correction of the de facto policy of assimilating minorities into the dominant American "melting pot" culture. This movement aims to promote the need for equal education for all races [9]. The pedagogical-epistemological credo of this movement is that the process of knowledge-formation is not merely an individual act, but based on the meanings created, formed, and awakened in a situational context (personal, social, 
historical, political, linguistic and cultural) 10]; and that education needs to be built on the perspective and awareness of the importance of socio-cultural diversity of society [11], [12].

To realize the mission of multicultural education based on this multicultural, among the experts emerged three typologies of multicultural education programs that are integrated into the curriculum. The three typologies of the program are: contentoriented programs; student-oriented programs; and sociallyoriented programs. The pedagogical and epistemological foundations of this movement, proposed by Banks through a "canon debate", which then formulate five typologies of knowledge, namely personal / cultural, popular, mainstream academic, transformative academic, and academic knowledge [13]. The most important of these knowledge typologies is the dichotomistic typology between "mainstream academic knowledge" versus "transformative academic knowledge".

In subsequent developments, this "new" pedagogy and epistemology gained the support of various language and cultural studies from a multicultural perspective, among others by [14], [15], [16]. Their research results negate the pedagogical and epistemological credo of the "essentialist curriculum" built on mainstream academic knowledge. According to them, the essential curricular necessity can inhibit the development of the cognitive progressive stages of learners, distort or destroy their "genuine concepts", "indigenous science", or "spontaneous concept" of the universe built and developed from their daily personal, social and cultural experience at community. The essentialist curriculum may also deprive learners of the real situation on which they are based and their use; is also less meaningful to them, and shows the existence of "educational hegemony or imperialism" of the learners themselves. In fact, the essentialist curriculum can distort or undermine the learners' self-concept which is an essential factor for the formation of the identity or character of the learner. [17]

To build character and nation needed political will or commitment from government or ruler. Character education is character education plus, that is education that involves aspects of knowledge (cognitive), feeling (feeling), and action (action) [18]. Without these three aspects character education will not be effective, and its implementation must be systematic and sustainable. With character education, a child will be emotionally intelligent. Emotional intelligence is the most important provision in preparing children for the future, because with it someone will be able to succeed in the face of all kinds of challenges, including the challenge to succeed academically [19].

Academically, character education is interpreted as value education, character education, moral education, character education whose goal is to develop the ability of learners to give good decisions, to maintain what is good, and to realize the goodness in everyday life with all my heart. The psychological content of character education includes the moral dimensions of reasoning, moral feeling, and moral behaviour [20].

"In character education, it is clear that we are willing to judge what is right, and what do we think to be right-in the face of pressure form without and temptation from within " [21]. In this connection, mentions some good values that need to be lived and familiarized in the lives of learners to create a harmonious life within the family and society. Some of these values include honesty, compassion, self-control, mutual respect or respect, cooperation, responsibility, and perseverance. Character education is not just an integrative dimension, in the sense of strengthening the intellectual morale of learners on the basis of virtue values so as to be a steady and test-resistant person, intelligent, independent, and conscientious person but also curative personally and socially [22].

Multicultural education is the desire of all people, because of the necessity of the concept of "humanizing human". Surely a human being who realizes his humanity will be in dire need of this multicultural education model education. [23]. By looking at and taking into account the various notions of multicultural education, it is concluded that multicultural education is a development process that does not recognize barriers in human interaction. As a vehicle for potential development, multicultural education is an education that values heterogeneity and plurality, an education that values cultural values, ethnicity, ethnicity and religion. The educational goals set by the state are mutually respectful agreements. As a consensus, the goal of education is not an unchanging dogma even a benchmark that is moving forward to better perfect the liberation of its citizens [24].

The basic principles of multicultural education implementation in Indonesia are cultured by the ethnic and cultural "majority" of WMPA. Therefore, to apply multicultural education in Indonesia must be careful, precise, and wise, because it is not necessarily the same as America. How can multicultural education be implemented in other countries outside the United States? How to transfer the concept of American-style multicultural education into a model appropriate to the conditions and needs of the Indonesian nation? Of course it needs correct adjustment and understanding [25]. In other words, if a multicultural education approach would be implemented in Indonesia, it should be based on the reality of Indonesia and local wisdom or indigenous knowledge in broad terms, he said with due regard to the characteristics of Indonesia's own nation and culture.

Multicultural education is defined as a social policy based on the principles of cultural preservation and mutual respect between all cultural groups within society. Multicultural learning is basically a nation's education program so that multicultural communities can participate in realizing an ideal democratic life for their people [26]. In a broad context, multicultural education seeks to help unite the nation democratically, emphasizing the perspective of plurality of peoples in different nations, ethnic, and cultural groups. Thus schools are conditioned to reflect the practice of democratic values.

Multicultural-based learning seeks to empower students to develop respect for people of different cultures, allowing them to work together with people or groups of people of different ethnicities or races directly. Multicultural education also helps students to acknowledge the appropriateness of diverse cultural views, assist students in developing pride in their cultural heritage, awaken students that value conflict is often the cause of conflict between community groups [27]. Multicultural 
education is organized in an effort to develop students' ability to view life from different cultural perspectives with their own culture, and to be positive about cultural, racial, and ethnic differences. The goals of multicultural-based education can be identified: (1) to enable the role of schools in view of the existence of diverse students; (2) to assist students in establishing positive treatment of cultural differences, racial, ethnic, religious groups; (3) providing student resilience by teaching them in their decisions and social skills; (4) to assist learners in building cross-cultural dependence and to give them a positive picture of group differences [28].

In addition, multicultural based learning is built on the concept of education for freedom that aims to: (1) help students or students develop knowledge, attitudes and skills to participate in democracy and freedom of society; (2) promoting freedom, competence, skills to cross ethnic and cultural boundaries to participate in other groups and cultures of others [29].

Education in the broad sense is the process of child culture to be formed according to the potential of learning it has with the aim to become a full member of the community who can live and practice its potential, both individually and together with other members. In a practical sense, education is a process of cultural delivery or cultural process that aims to make children have the skills, knowledge, attitudes, values, and patterns of certain behaviors. Referring to an understanding of the broad sense and practical meaning, education aims to transform culture, whether in the household (family), in community, as well as in school, which shows what is good in society [30].

The Government of Indonesia through the Ministry of Education and Culture has launched character education from elementary to university level. According to Ministry of Education and Culture, Muhammad Nuh, the formation of character needs to be done from an early age. If the character has already formed an early age, it will not be easy to change a person's character [31]. The importance of education in shaping the character of a multicultural Indonesian man. Therefore, there needs to be an effort to develop character education model based on multicultural. The development of multicultural-based character education model is very urgent, considering the recent erosion of Indonesian human character that has diverse cultures.

To obtain a clear picture of the dynamics of historical learning model in Unimed Higher Colleges, the study entitled "Development of Character Based Learning Model with Multicultural Scientific Approach to Improve the Quality of Learning in History Education" Through research and development it is very important to do to shape the character academic multicultural scientific approach.

\section{METHOD}

The research begins with a preliminary study, literature study, field conditions, supporting facilities and infrastructure. The analysis is done on entrepreneurship courses on the curriculum and course structure that will be taught to the students by knowing the extent of coverage, time allocation, learning strategy, learning method, and instructional media used. The product produced at the end of this study is a character-based learning model with a multicultural scientific approach to improve the quality of learning in historical education.

This research is a research and development (Research \& Development). This research and development consists of three stages: pre model development, model development and application of model where research refers to R \& D cycle [32]. The study was conducted in the Department of History Education Faculty of Social Science Unimed. Both expert validation, individual trials, small group trials, and major trials were conducted at Unimed. Research subjects are students and lecturers.

Data collection in research and development is grouped into three, namely preliminary study, development, and validation test. In each stage of the study selected specific data collection techniques in accordance with their respective objectives. In the preliminary study, questionnaire / questionnaire, observation, and documentation were selected, in addition to literature review. In general, third, the technique is used simultaneously and complementary.

Data analysis technique in this research and development using descriptive analysis qualitative and quantitative. All the data collected were analyzed by descriptive statistical techniques that were quantitatively segregated by category to sharpen judgments in drawing conclusions, data reduction, display data decision-making and verification.

This research is a research development (Research and Development) with qualitative and quantitative approach. Research begins with "photographing" North Sumatra Culture include: South Tapanuli, Deli Serdang, Medan City, Labuhan Batu, Labuhan Batu Selatan, Tanah Karo Regency with Batak tribe include; Batak Simalungun, Batak Papak, Batak Mandailing, Batak Karo, Batak Toba, Batak Sipirok Angkola and after found hypothetical development model through FGD, validation result, standard setting and development concept, then tested to Unimed History student, handled by development team.

Instrument of data collection in this qualitative research, researcher as key instrument (key instruments). Qualitative measures of behavioral observation, direct questioning, direct disclosure, and covert measurement. Test of validity of qualitative data include (1) test of credibility (internal validity); (2) transferability (external validity); (3) dependability (reliability); and (4) confirmability (objectivity). This analysis process consists of three sequences of activities simultaneously, continuously, continuously over and over, as a series of mutual follow-on analysis activities. Stages of analysis using Spradley model analysis, the research process departs from a wide, then focus and expand again. Stages performed are domain analysis, taxonomy, compositional and cultural theme analysis. Measurements in this study also apply descriptive statistical analysis.

\section{RESULTS}

The results of this study found that the preparation of the multicultural learning history design can be done through five main stages: (1) content analysis; (2) cultural background analysis (setting analysis); (3) maping contents; (4) organizing 
the material (contents organizing) learning History; and (5) pouring in the learning format. The five stages of the process in formulating the historical learning plan can be described as follows:

- Content analysis, namely the process to identify, select, and determine the learning material History. This process can be pursued by guidance or use of material signs contained in the GBPP, including the minimum standard materials, sequences and scope of materials, basic competencies, and skills developed. In addition, in analyzing the lecturers' materials should also use a moralvalue approach, whose characteristics include moral knowledge, moral recognition, moral habituation and moral acting.

- Cultural background analysis developed from cultural approach and life cycles (life clycle), which contains two concepts, namely the concept of region or environment (local, regional, national and global); and human concept and its activities covering all aspects of life. In addition, background analysis also considers the cultural values that grow and develop and highly upheld by a society and the possibilities of its usefulness for student life.

- Mapping learning materials that are closely related to principles that must be developed in teaching values and morals, namely the principle: from easy to difficult; from simple to difficult; from concrete to abstract; from a narrow / close environment to a widespread environment.

- Organizing Historical Materials, with a multicultural approach must be done with regard to the principles of "4 W and $1 \mathrm{H}$ ", namely: What, Why, When, Where and How. In the design of learning, the five principles, must be colored by the characteristics of learning with multicultural, in the direction of moral-based experience, based on the principle of high empathicity and honesty and mutual respect for their respective advantages. In addition, the organizing of learning materials needs to consider several dimensions that are able to describe the characteristics of multicultural work, including content integration, knowledge construction, prejudice reduction, (eguitable pedagogy), and the dimension of empowering the school culture and social structure (Empawering school culture and social structure). All of these are done by empowering the method of learning that enables the students to be cultured.

- Pouring into the stages of multicultural-based learning model. Stages of action process undertaken in developing multicultural learning-based learning are put forward in the following matrix.

TABLE I. STUDY LEARNING PROCESS STUDY HISTORY STUDY

\begin{tabular}{|c|c|c|}
\hline No & Learning Stages & Event Description \\
\hline 1. & $\begin{array}{l}\text { Study of self- } \\
\text { exploration and } \\
\text { socio-cultural } \\
\text { (local) } \\
\text { environment of } \\
\text { potential students } \\
\text { with } \\
\text { multicultural }\end{array}$ & $\begin{array}{l}\text { Assigned to conduct local exploration, which } \\
\text { includes the self and the socio-cultural } \\
\text { environment of multiculturalism, with the } \\
\text { following provisions: } \\
\text { a. Choose an issue that interests them ;; } \\
\text { b. Describes how his expression is } \\
\text { c. Digging out the philosophical values and } \\
\text { foundations used by the people of origin; }\end{array}$ \\
\hline
\end{tabular}

\begin{tabular}{|c|c|c|}
\hline No & Learning Stages & Event Description \\
\hline & $\begin{array}{l}\text { substance } \\
\text { Presentation of } \\
\text { exploration } \\
\text { results. }\end{array}$ & $\begin{array}{l}\text { d. Projecting the prospects of values and } \\
\text { philosophy of selected issues in the context } \\
\text { of community life and nation and state. }\end{array}$ \\
\hline 2. & $\begin{array}{l}\text { Presentasi hasil } \\
\text { eksplorasi. }\end{array}$ & $\begin{array}{l}\text { Present exploration results on local issues of } \\
\text { interest to him, in the presence of friends or } \\
\text { other groups. }\end{array}$ \\
\hline 3. & $\begin{array}{l}\text { Peer group } \\
\text { analysis }\end{array}$ & $\begin{array}{l}\text { Analyze and comment on the presentation of } \\
\text { exploratory results of selected issues. Lecturers } \\
\text { record some feedback and comments that } \\
\text { appear between them. }\end{array}$ \\
\hline 4. & Expert opinion & $\begin{array}{l}\text { The lecturer gives comments on the } \\
\text { exploration results presented and some friends } \\
\text { comments. }\end{array}$ \\
\hline 5. & $\begin{array}{l}\text { Reflection, } \\
\text { recommendations } \\
\text { and commitment } \\
\text { building }\end{array}$ & $\begin{array}{l}\text { The lecturer gives comments on the } \\
\text { exploration results presented and some friends } \\
\text { comments. }\end{array}$ \\
\hline
\end{tabular}

The first process in the development of historical characterbased learning model with a multicultural scientific approach is to analyze the needs of students who have course of history education in the Odd semester is the academic year 2016/2017 by distributing questionnaires / questionnaires to 4 lecturers and 68 students by first outlining the definition of interactive learning in the questionnaire so that the respondents have a description of the questions in the questionnaire submitted. The search results from the questionnaire were found that $88 \%$ of the lecturers and had taught the history education course stated that they need interactive learning in the learning process to make the learning process run more effectively, and $92 \%$ of students stated that they need a character-based history learning model with multicultural they can make as a means of learning individually. The data needs analysis is shown in the following table.

TABLE II. DATA ANALYSIS OF THE NEED FOR HISTORY LEARNING MODEL DEVELOPMENT BASED ON CHARACTER WITH SCIENTIFIC APPROACH MULTICULTURAL

\begin{tabular}{|c|l|c|c|c|c|}
\hline \multirow{2}{*}{ No } & \multicolumn{1}{|c|}{ Data Information } & \multicolumn{3}{|c|}{ Frequency } & \multirow{2}{*}{ \% } \\
\cline { 3 - 5 } & & $\begin{array}{c}\text { Lect } \\
\text { ure }\end{array}$ & $\begin{array}{c}\text { Stud } \\
\text { ent }\end{array}$ & Sum & \\
\hline 1. & Urgen and important to be & 5 & 71 & 76 & 95,00 \\
& developed related to character- & 0 & 9 & 9 & 11,25 \\
& based multicultural scientific & & & & \\
& approach & & & & \\
\hline 2 & Build awareness of the & 4 & 67 & 71 & 88,75 \\
& importance of time and place in & 1 & 13 & 14 & 17,50 \\
& history. & & & & \\
\hline 3 & Exercise critical power to & 5 & 74 & 79 & 98,75 \\
& understand historical facts & 0 & 6 & 6 & 7,50 \\
\hline 4 & Grow students' appreciation & 4 & 70 & 74 & 92,50 \\
& and appreciation of historical & 1 & 10 & 11 & 13,00 \\
& relics & & & & \\
\hline 5 & Fostering an understanding of & 5 & 68 & 73 & 91,25 \\
& the process of Indonesia's & 0 & 12 & 12 & 15,00 \\
& formation through history & & & & \\
\hline 6 & Growing awareness within the & 5 & 69 & 74 & 92,25 \\
& self as part of the Indonesian & 0 & 11 & 11 & 13,75 \\
& nation & & & & \\
\hline 7 & Has the possibility to be & 4 & 74 & 78 & 87,50 \\
& developed & 1 & 6 & 7 & 8,75 \\
\hline 8 & Have the skills, knowledge and & 3 & 67 & 70 & 87,50 \\
& experience & 2 & 13 & 15 & 18,75 \\
\hline 9 & Is a solution to improve / & 4 & 64 & 68 & 85,00 \\
& improve competence & 1 & 16 & 17 & 21,25 \\
\hline \multirow{2}{*}{} & & & & \\
\hline
\end{tabular}




\begin{tabular}{|c|l|c|c|c|c|}
\hline \multirow{2}{*}{ No } & \multicolumn{1}{|c|}{ Data Information } & \multicolumn{3}{|c|}{ Frequency } & \multirow{2}{*}{ \% } \\
\cline { 3 - 5 } & & $\begin{array}{c}\text { Lect } \\
\text { ure }\end{array}$ & $\begin{array}{c}\text { Stud } \\
\text { ent }\end{array}$ & Sum & \\
\hline 10 & Character Based History & 4 & 75 & 79 & 98,75 \\
& Learning with Scientific & 1 & 5 & 6 & 7,50 \\
& Multicultural Approach & & & & \\
\hline \multirow{2}{*}{11} & $\begin{array}{l}\text { Historical learning process with } \\
\text { development of Scientific }\end{array}$ & 5 & 68 & 73 & 91,25 \\
& Multicultural Approach & & 12 & 12 & 15,00 \\
\hline
\end{tabular}

The result of the analysis of the overall development needs can be concluded that the percentage of answers given to lecturers pengampu history courses or who teach history almost shows a very good assessment of the average $92.45 \%$ while to students who have taken the course of history on the development model will be developed showing good answers and giving an average answer of $93.34 \%$. So it can be concluded that the development of character-based learning modle with a multicultural scientific approach can be developed and soon will provide new learning model products suitable and suitable for learning history.

TABLE III. DATA OF FEASIBILITY MODEL LEARNING LEARNING LEARNING HISTORY BASED CHARACTER WITH SCIENTIFIC MULTICULTURAL APPROACH

\begin{tabular}{|c|c|c|c|c|}
\hline No. & $\begin{array}{c}\text { Aspect of } \\
\text { Assessment }\end{array}$ & Description & $\%$ & Criteria \\
\hline \multirow[t]{6}{*}{1.} & \multirow{6}{*}{$\begin{array}{l}\text { Study of self- } \\
\text { exploration } \\
\text { and socio- } \\
\text { cultural } \\
\text { environment } \\
\text { of potential } \\
\text { students with } \\
\text { multicultural } \\
\text { substance }\end{array}$} & $\begin{array}{l}\text { Conducting local exploration, } \\
\text { which includes the self and the } \\
\text { socio-cultural environment }\end{array}$ & $\begin{array}{l}88, \\
45\end{array}$ & $\begin{array}{c}\text { Very } \\
\text { feasible }\end{array}$ \\
\hline & & $\begin{array}{l}\text { Choose an issue that interests } \\
\text { them }\end{array}$ & $\begin{array}{l}85 . \\
23\end{array}$ & $\begin{array}{c}\text { Very } \\
\text { feasible }\end{array}$ \\
\hline & & Describes how his expression is & $\begin{array}{l}86, \\
56\end{array}$ & $\begin{array}{c}\text { Very } \\
\text { feasible }\end{array}$ \\
\hline & & $\begin{array}{l}\text { Digging philosophical values } \\
\text { and foundations }\end{array}$ & $\begin{array}{l}86, \\
23 \\
\end{array}$ & $\begin{array}{c}\text { Very } \\
\text { feasible }\end{array}$ \\
\hline & & $\begin{array}{l}\text { Projecting the prospects of } \\
\text { values and philosophy of } \\
\text { selected issues }\end{array}$ & $\begin{array}{l}85 \\
78\end{array}$ & $\begin{array}{c}\text { Very } \\
\text { feasible }\end{array}$ \\
\hline & & $\begin{array}{l}\text { Analyze the exploration results } \\
\text { from the socio-cultural } \\
\text { environment }\end{array}$ & $\begin{array}{l}82, \\
45\end{array}$ & $\begin{array}{c}\text { Very } \\
\text { feasible }\end{array}$ \\
\hline \multirow[t]{3}{*}{2} & \multirow{3}{*}{$\begin{array}{l}\text { Presentation } \\
\text { of } \\
\text { exploratory, } \\
\text { scientific and } \\
\text { character } \\
\text { results }\end{array}$} & Presenting exploration results & $\begin{array}{l}83, \\
44\end{array}$ & $\begin{array}{c}\text { Very } \\
\text { feasible }\end{array}$ \\
\hline & & $\begin{array}{l}\text { Conduct a deep debate / } \\
\text { assessment of cultural aspects }\end{array}$ & $\begin{array}{l}86, \\
89\end{array}$ & $\begin{array}{c}\text { Very } \\
\text { feasible }\end{array}$ \\
\hline & & $\begin{array}{l}\text { Provide a detailed description } \\
\text { of the activities that have been } \\
\text { done }\end{array}$ & $\begin{array}{l}88, \\
45\end{array}$ & $\begin{array}{c}\text { Very } \\
\text { feasible }\end{array}$ \\
\hline \multirow[t]{4}{*}{3.} & \multirow{4}{*}{$\begin{array}{l}\text { Peer group } \\
\text { analysis } \\
\text { scientific and } \\
\text { character }\end{array}$} & $\begin{array}{l}\text { Analyze by commenting on } \\
\text { observations }\end{array}$ & $\begin{array}{l}85 . \\
23\end{array}$ & $\begin{array}{c}\text { Very } \\
\text { feasible }\end{array}$ \\
\hline & & $\begin{array}{l}\text { Comment on the presentation } \\
\text { of exploration results }\end{array}$ & $\begin{array}{l}86, \\
56\end{array}$ & $\begin{array}{c}\text { Very } \\
\text { feasible }\end{array}$ \\
\hline & & Present the results of the task & $\begin{array}{l}86, \\
23\end{array}$ & $\begin{array}{c}\text { Very } \\
\text { feasible }\end{array}$ \\
\hline & & $\begin{array}{l}\text { Record and record some } \\
\text { feedback from the presentation }\end{array}$ & $\begin{array}{l}88, \\
45\end{array}$ & $\begin{array}{c}\text { Very } \\
\text { feasible }\end{array}$ \\
\hline \multirow[t]{2}{*}{4} & \multirow[t]{2}{*}{$\begin{array}{l}\text { Expert } \\
\text { opinion }\end{array}$} & $\begin{array}{l}\text { The lecturer gives comment on } \\
\text { the exploration result }\end{array}$ & $\begin{array}{l}85 . \\
23 \\
\end{array}$ & $\begin{array}{c}\text { Very } \\
\text { feasible }\end{array}$ \\
\hline & & $\begin{array}{l}\text { Neighbor groups nor comment } \\
\text { on each other and build }\end{array}$ & $\begin{array}{l}86, \\
56\end{array}$ & $\begin{array}{c}\text { Very } \\
\text { feasible }\end{array}$ \\
\hline \multirow[t]{3}{*}{5} & \multirow{3}{*}{$\begin{array}{l}\text { Reflection, } \\
\text { recommendat } \\
\text { ions and } \\
\text { commitment } \\
\text { building }\end{array}$} & Lecturers with students reflect & $\begin{array}{l}86, \\
23\end{array}$ & $\begin{array}{c}\text { Very } \\
\text { feasible }\end{array}$ \\
\hline & & $\begin{array}{l}\text { The lecturer recommends the } \\
\text { superiority and uniqueness of } \\
\text { cultural values }\end{array}$ & $\begin{array}{l}88, \\
78\end{array}$ & $\begin{array}{c}\text { Very } \\
\text { feasible }\end{array}$ \\
\hline & & $\begin{array}{l}\text { Lecturers build value } \\
\text { commitments }\end{array}$ & $\begin{array}{l}89, \\
45\end{array}$ & $\begin{array}{c}\text { Very } \\
\text { feasible }\end{array}$ \\
\hline
\end{tabular}

\begin{tabular}{|c|c|c|c|c|}
\hline No. & $\begin{array}{c}\text { Aspect of } \\
\text { Assessment }\end{array}$ & Description & $\%$ & Criteria \\
\hline & & Students build value & 88, & Very \\
& & commitments & 44 & feasible \\
\hline & & Average value & 87, & Very \\
& & & 63 & feasible \\
\hline
\end{tabular}

The result of the assessment and the response of the test to the whole student then it is concluded that the percentage of average value from each aspect of the valuation is $87,63 \%$. Where if the range is at a score of $81 \% \leq X \leq 100 \%$ then the tendency of the limited trial results is categorized as "very feasible".

\section{IV.DISCUSSION}

Assessment of product development aspect of characterbased history learning model with multicultural approach in research and development is determined by: (1) self-exploration study and potential student social environment with multicultural substance; (2) presentation of exploratory, scientific and character results; (3) peer group analysis scientific and character; (4) expert opinion; (5) reflection, recommendation and commitment building. as a whole shows a very worthy assessment, both given to students as well as by the instructional design experts and historical learning media. this suggests that the learning model is closely related to the limits of the aspect if it wants a good and appropriate learning in historical education. Especially that berkauitan with local cultural character as well as multicultural scientific.

History education lectures should provide a fun atmosphere, full of cultural values and formally, the internalization of moral values through the development of capabilities into the affective domain of cognitive, affective, and psychomotor has been formulated in the education policy in Indonesia but less clearly its implementation because of more emphasis on cognitive development.

The development of multicultural-based character education model is integrative, compact, and consistent. Integrative means integrating multicultural-based character education into all programs and activities in college. Compact means that all components of education have the same attitude and views in implementing character-based multicultural education. Consistent means that all components of education have consistent attitudes and views in applying multicultural-based character education.

Lecturers have a very important role in the development of a character-based learning model with a multicultural scientific approach to improve the quality of learning in historical education through teaching responsive learning planning. Implementation of multicultural-based character education in universities requires an appropriate, effective, and participatory strategy involving all components of education. The accuracy of selection strategy will provide optimal results in forming students with character. Thus the development of learning models of character education implementation as a strategy of implementing character education based on multicultural is very important. 


\section{CONCLUSION}

Character-based history education with a multicultural scientific objective aims to form and build the mindset, attitude, and behavior of students to be a positive person, morals karimah, spirited, and responsible. In the context of education, character and cultured education is a conscious effort undertaken to form students into positive and morally appropriate people in accordance with the standard of graduation and learning achievement in teaching planning so that it can be implemented in everyday life and uphold their culture.

Multicultural learning models as well as multiethnic form to be able to break the encapsulation of ethnic and other social cultural insulation. In addition, universities are expected to develop students to become ethnic literacy creatures and cultural literacy. Cultural diversity is born by various aspects of life, such as religion, ethnicity, heredity, socioeconomic conditions, and stages of power.

\section{REFERENCE}

[1] E.J. Hobsbaum. Nasionalisme Menjelang Abad XXI, Penerjemah: Hajartian Silawati, Yogyakarta: Tiara Wacana. Abdullah, Taufik, Ed. "Di Sekitar Sejarah Lokal di Indonesia", dalam Sejarah Lokal di Indonesia, Yogyakarta: Gajah Mada University Press. 1990, pp. 210211.

[2] T. Abdullah, "Nasionalisme Indonesia: Dari asal-usul ke prospek masa depan" dalam Sejarah, Jakarta: MSI dan Arsip Nasional RI., 1999, p. 73.

[3] I. Kleden, Menulis Politik: Indonesia Sebagai Utopia, Jakarta: Penerbit Buku Kompas, 2001, p. 73.

[4] M. Simatupang, Budaya Indonesia yang Supraetnis, Jakarta: Sinar Sinanti. 2002, p, 45

[5] J.H. Robinson, The New History, New York: The Free Press. Burke, 1965.

[6] S.H. Hasan,.S.H."Pendidikan Sejarah Untuk Membangun Manusia Baru Indonesia", dalam Mimbar Pendidikan, Nomor 2 Tahun XVIII, Bandung IKIP Bandung,1999, pp. 4-11.

[7] S.H. Hasan, "Pendidikan Sejarah Untuk Membangun Manusia Baru Indonesia", dalam Mimbar Pendidikan, Nomor 2 Tahun XVIII, Bandung IKIP Bandung, 1999.

[8] B. Anderson, Imagined Communities: Reflections on the Origin and Spread of Nationalism, London: The Thetford Press Ltd. 1983, p. 1216.

[9] S.E. Fillion, Multicultural curriculum. Diunduh 11 Agustus, 2015 dari www.txstate.edu/edphd/PDF/multicultural.pdf

[10] M.L. Dantas, Building teacher competency to work with diverse learners in the context of international education. Teacher Education Quarterly, Winter 2007.

[11] J.A. Banks, Aintroduction to multicultural education (2nd ed.). Boston: Allyn and Bacon, 1999.

[12] S.E. Fillion, Multicultural curriculum. Diunduh 11 Agustus, 2015 dari www.txstate.edu/edphd/PDF/multicultural.pdf

[13] J.A. Banks, Multicultural education: Transformative knowledge and action: historical and contemporary perspectives. New York, Teachers College Press, 1996.

[14] Zamroni. School and university colaboration for improving science and mathematics instruction in school. Paper presented at the National Seminar on Science and Mathematic Education. Bandung, August, 21, 2001.

[15] W.B. Stanley, \& N.W. Brickhouse, The multicultural question revisited. Science Education. 85(1). 35-48. diunduh 12 Agustus 2015, dari http://faculty.ed.uiuc.edu/m-osbor/507SE06/stanleybrickhouse2001.pdf

[16] M. Ogawa, Science as the culture of scientist: How to cope with scientism? Diunduh 27 Januari 2015 dari www.ouhk.edu.hk/cridal/misc/ogawa.htm.
[17] M. Sumantri, Pengembangan potensi peserta didik dengan kurikulum terpadu untuk menjadi manusia indonesia seutuhnya. Pidato pengukuhan jabatan Guru Besar tetap dalam bidang Ilmu Perencanaan Kurikulum pada FIP-UPI. Bandung:UPI, 2002.

[18] Zamroni. Pendidikan demokrasi pada masyarakat multikultural. Yogyakarta: Gavin Kalam Utama, 2001.

[19] Lickona, T. Educating for character: How our schools can teach respect and responsibility. New York: Bantam Books, 1991.

[20] Lickona, T., Schaps, E., and Lewis, C. Eleven principles of effective character education. Washington, D.C.: Character Education Partnership, 1995.

[21] Lickona, T. Educating for character: How our schools can teach respect and responsibility. New York: Bantam Books, 1991.

[22] Lickona, T., Schaps, E., and Lewis, C. Eleven principles of effective character education. Washington, D.C.: Character Education Partnership, 1995.

[23] Mahfud, Chairul. (2006). Pendidikan Multikultural. Yogyakarta: Pustaka Pelajar, p. 70

[24] Tilaar, H.A.R, (2006). Manifesto Pendidikan Nasional, Tinjauan dari Perspektif Postmodernisme dan Studi Kultural. (Jakarta: Kompas, 2006), hlm. 112.

[25] Zamroni. (2011a). Pendidikan demokrasi pada masyarakat multikultural. Yogyakarta: Gavin Kalam Utama, p. 159.

[26] Banks, J.A., Cortes, C.E., Gay, G., Garcia, R.L., \& Ochoa, A. (1992). Curriculum guidelines for multicultural education (Rev. ed.), Washington, DC: National Council for the Social Studies.

[27] Savage, T.V.,\& Armstrong, D.G. (1996). Effective Teaching in Elementary Social Studies. Ohio: Prentice Hall.

[28] Banks, J.A. (1995). Transformative challenges to the social sciences disciplines: implications for social studies teaching and learning. Theory and Research in Social Education, XXIII(1), 2-20.

[29] Banks, J.A. (1997). Teaching strategies for ethnic studies (6th ed.). Boston: Allyn and Bacon.

[30] Sagala, Syaiful. (2006). Manajemen Berbasis Sekolah dan Masyarakat, Strategi Memenangkan Persaingan Mutu. Jakarta: PT Rakasta Samasta, p. 227.

[31] Husaini, Adian. (2010). "Membentuk Manusia Berkarakter dan Beradab".Makalah. Program Studi Pendidikan Umum Sekolah Pascasarjana Universitas Pendidikan Bandung. Bandung, 28 Juli 2010, p. 1.

[32] Borg, Walter R. \& Gall, Meredith Damien. (1983). Educational Research An Introduction. New York: Longman Inc. 